\title{
Molecular and Electrical Abnormalities in the Mouse Model of Amyotrophic Lateral Sclerosis
}

\author{
Katharina A. Quinlan ${ }^{1}$, Sherif M. Elbasiouny ${ }^{1}$ and C.J. Heckman ${ }^{1,2,3}$ \\ ${ }^{1}$ Department of Physiology, Northwestern University Feinberg School of Medicine \\ ${ }^{2}$ Department of Physical Medicine and Rehabilitation, \\ Northwestern University Feinberg School of Medicine \\ ${ }^{3}$ Department of Physical Therapy and Human Movement Sciences, \\ Northwestern University Feinberg School of Medicine \\ United States of America
}

\section{Introduction}

Amyotrophic lateral sclerosis (ALS) is a devastating, fast progressing and fatal disease for which there is little treatment. It is marked by loss of spinal and cortical motoneuron function. Many parameters are altered in the time leading up to this loss, including electrical properties, endoplasmic reticulum (ER) stress, glial functioning, glutamate signaling, protein degradation, mitochondrial functioning, axonal transport, and immune response. This chapter concentrates on the interplay between altered electrophysiological properties and molecular events. Emphasis is placed on the changes that precede overt symptom onset and results are mainly drawn from studies using the rodent models of ALS.

\section{ALS animal models}

Most cases of ALS are spontaneous (sALS), while the heritable form, familial ALS (fALS), represents about $5 \%$ of total ALS cases (Byrne et al., 2011). Of fALS patients, $20 \%$ have a mutation in the gene that encodes for the superoxide dismutase 1 (SOD1) copper/zinc enzyme (Rosen et al., 1993), 5\% have a mutation in the TARDBP gene which encodes DNAbinding protein 43 (TDP-43), another $5 \%$ have a mutation in the FUS gene which encodes for the fused in sarcoma FUS/TLS protein (Mackenzie et al., 2010), some possess a mutation in the gene encoding vesicle-associated membrane protein (VAPB) (Nishimura et al., 2004), and a new study shows that some of those remaining have a mutation in the gene coding for the ubiquitin-like protein ubiquilin-2 (Deng et al., 2011). Transgenic mice expressing one of the various mutations of human SOD1, hereafter referred to as SOD1 mice; (Gurney et al., 1994, Bruijn et al., 1997, Zhang et al., 1997) are very common animal models of ALS; numerous other models of fALS are reviewed by Van Den Bosch (2011). It is not known how the SOD1 mutation leads to the degeneration of motoneurons, though it is probably not due to loss of its normal function converting superoxide into hydrogen peroxide. The mutant, misfolded protein likely possesses a toxic gain-of-function, as some mouse lines retain nearly normal levels of SOD1 enzymatic activity and still develop the disease, while SOD1 
knockout mice, which do not possess any SOD1 enzymatic activity, do not develop the disease (Gurney et al., 1994, Reaume et al., 1996, Wong et al., 1995). Whatever the mechanism(s) leading to neurodegeneration, it is not immediate. The SOD1 enzyme is present throughout the nervous system (Pardo et al., 1995) starting embryonically, but does not lead to onset of overt symptoms until well into adulthood, even in mice that express high levels of the protein (Gurney et al., 1994). And within the nervous system, only certain neurons show susceptibility to the disease. This chapter will explore the earliest signs of malfunction in the neurons that are most vulnerable to the disease.

\section{Timeline of deficits}

In ALS, it is difficult to assess which of all the processes that have been found to be altered are causal to neurodegeneration and which are homeostatic, adaptive mechanisms that are actually allowing the maintenance function. Despite this, it is useful to map out the timing of the various altered properties collected from the mouse models, as presented in Figure 1. Depending on the particular SOD1 mouse model studied, the magnitude and timing of alterations observed does vary (reviewed in Elbasiouny et al, previous chapter). However, for this chapter, the deficits in these mice will be considered in their entirety and not separated based on the particular model from which the results were obtained.

Long before the onset of overt symptoms, within the first week after birth, electrical properties are altered. These properties include an increase in excitability (as measured by both the $\mathrm{Na}^{+}$- and $\mathrm{Ca}^{2+}-$ mediated persistent inward current; PIC) and an increased neuronal size (including increased dendritic branching and increased specific input conductance). Significantly larger PICs first appear in cultured embryonic spinal and cortical motoneurons (Kuo et al., 2005, Pieri et al., 2009), persist at an age of about one week in spinal and hypoglossal motoneurons (van Zundert et al., 2008, Quinlan et al., 2011) and are likely still present in the spinal and cortical motoneurons of adults (Carunchio et al., 2010, Meehan et al., 2010). Interestingly, although the PIC is upregulated very early, what might otherwise be the beginning of motoneuron hyperexcitability is instead moderated by changes in size and specific input conductance (Amendola and Durand, 2008, Elbasiouny et al., 2010, Quinlan et al., 2011). In adulthood, but still well before the onset of symptoms, there are signs of defective protein degradation, endoplasmic reticulum (ER) stress, impaired axon transport, and deficiencies in mitochondrial function. Signs of aberrant protein clearance include increased expression of genes related to ubiquitination, UPR, and ER stress (Saxena et al., 2009). As these changes might suggest, there is a buildup of insoluble SOD1 proteins at this time (Johnston et al., 2000, Turner et al., 2003a), followed shortly by fragmentation of the Golgi (Mourelatos et al., 1996). The next signs of impairment appear in the mitochondria and in the cellular transport system (Zhang et al., 1997, Warita et al., 1999, Williamson and Cleveland, 1999, Mattiazzi et al., 2002, Kieran et al., 2005, Damiano et al., 2006, De Vos et al., 2007, Bilsland et al., 2008, Jaiswal et al., 2009, Nguyen et al., 2009, Bilsland et al., 2010, Li et al., 2010). The immune response is initiated next (Alexianu et al., 2001, Chiu et al., 2008, Gowing et al., 2008, Chiu et al., 2009). After this, denervation of the motor units and loss of maximal force begins (Kennel et al., 1996, Frey et al., 2000, Fischer et al., 2004, Hegedus et al., 2007, Hegedus et al., 2008), but the impairment of normal function in the mouse is subtle and onset of overt symptoms is several weeks off, even in the most severe models. Just before the impending functional loss, several of the 
last changes before overt onset of symptoms involve the glia: activation of astrocytes, expression of different splice variants of EAAT2, decreased expression of the GluR2 subunit, and decreased number of glial $\mathrm{K}^{+}$channels (Bruijn et al., 1997, Bendotti et al., 2001, Sasaki et al., 2001, Munch et al., 2002, Warita et al., 2002, Fischer et al., 2004, Ignacio et al., 2005, Kaiser et al., 2006).

It is tempting to assume that the order of appearance of the altered parameters represents a chain reaction of events, but this is not necessarily the case. There is considerable interplay between these components within the neurons, such that one pathway cannot be altered without affecting any other aspect of cellular or synaptic function. These interactions will be considered next.

\section{Calcium: No buffer for increased currents}

Entry of $\mathrm{Ca}^{2+}$ occurs through voltage-gated $\mathrm{Ca}^{2+}$ channels and through ligand-gated channels activated by glutamate, particularly the NMDA-type glutamate receptors and those AMPA-type glutamate receptors which lack the $\mathrm{Ca}^{2+}$-impermeable GluR2 subunit. Most voltage-gated $\mathrm{Ca}^{2+}$ channels open only when the cell depolarizes; however, the L-type $\mathrm{Ca}_{\mathrm{v}} 1.3$ channels, which contribute to the PIC, open near the resting membrane potential ($40 \mathrm{mV}$ ) and allow some $\mathrm{Ca}^{2+}$ influx even when the neuron is at rest ( $\mathrm{Xu}$ and Lipscombe, 2001). There is very little expression of $\mathrm{Ca}_{\mathrm{v}} 1.3$ channels in spinal motoneurons at birth, but $\mathrm{Ca}_{\mathrm{v}} 1.3$ channels are increasingly present as the motoneurons mature, reaching adult levels by postnatal day 18 (P18) in mice, (Jiang et al., 1999, Quinlan et al., 2011). The PIC sets the level of excitability in neurons: PICs allow neurons to repetitively fire action potentials, and with large PICs, neurons can sustain firing long after the depolarizing stimulus is removed (Heckman et al., 2008). In addition, motoneurons from SOD1G93A-high-expressor mice show a significantly larger PIC during postnatal development, including significantly larger amplitudes of both $\mathrm{Ca}^{2+}$ and $\mathrm{Na}^{+}$currents (Quinlan et al., 2011). Larger PICs can increase the overall excitability of a neuron (though other factors, like size, can mitigate this), and the influx of $\mathrm{Ca}^{2+}$ could have many other consequences in cell-signaling. An increased PIC is found in cultured, embryonic, SOD1G93A-high motoneurons (both spinal and cortical), though at this point the PIC is completely $\mathrm{Na}^{+}$-based (Kuo et al., 2005, Pieri et al., 2009). Postnatally, both spinal and brainstem SOD1 motoneurons show an increased PIC (van Zundert et al., 2008, Quinlan et al., 2011), and indirect evidence suggests larger PICs persist into adulthood in SOD1 cortical and spinal motoneurons (Carunchio et al., 2010, Meehan et al., 2010). In addition to the maturation of the PIC, there is an increase in AMPA-type glutamate receptors on motoneurons (Vinay et al., 2000). These receptors normally would not contribute to $\mathrm{Ca}^{2+}$ influx since, due to a single amino acid in the pore-forming GluR2 subunit they are impermeable to $\mathrm{Ca}^{2+}$. However, in presymptomatic SOD1 motoneurons, there are fewer $\mathrm{Ca}^{2+}$-impermeable GluR2 subunits; and more $\mathrm{Ca}^{2+}$-permeable GluR3 subunits (Tortarolo et al., 2006). In sALS patients, AMPA receptors also are more $\mathrm{Ca}^{2+}$ permeable, but through a different mechanism. Spinal motoneurons of symptomatic sALS patients, but not SOD1 rats, showed inefficient editing of the mRNA, resulting in mutant, GluR2Q subunits that are $\mathrm{Ca}^{2+}$-permeable (Kawahara et al., 2004, Kwak and Kawahara, 2005, Kawahara et al., 2006). As motoneurons mature they must cope with an everincreasing burden of $\mathrm{Ca}^{2+}$ influx through voltage-gated $\mathrm{Ca}^{2+}$ channels (as the $\mathrm{Ca}^{2+} \mathrm{PIC}$ increases with age) and SOD1 motoneurons have a heavier burden due to potentiation of the $\mathrm{Ca}^{2+} \mathrm{PIC}$ and altered AMPA receptors which are more $\mathrm{Ca}^{2+}$-permeable. 


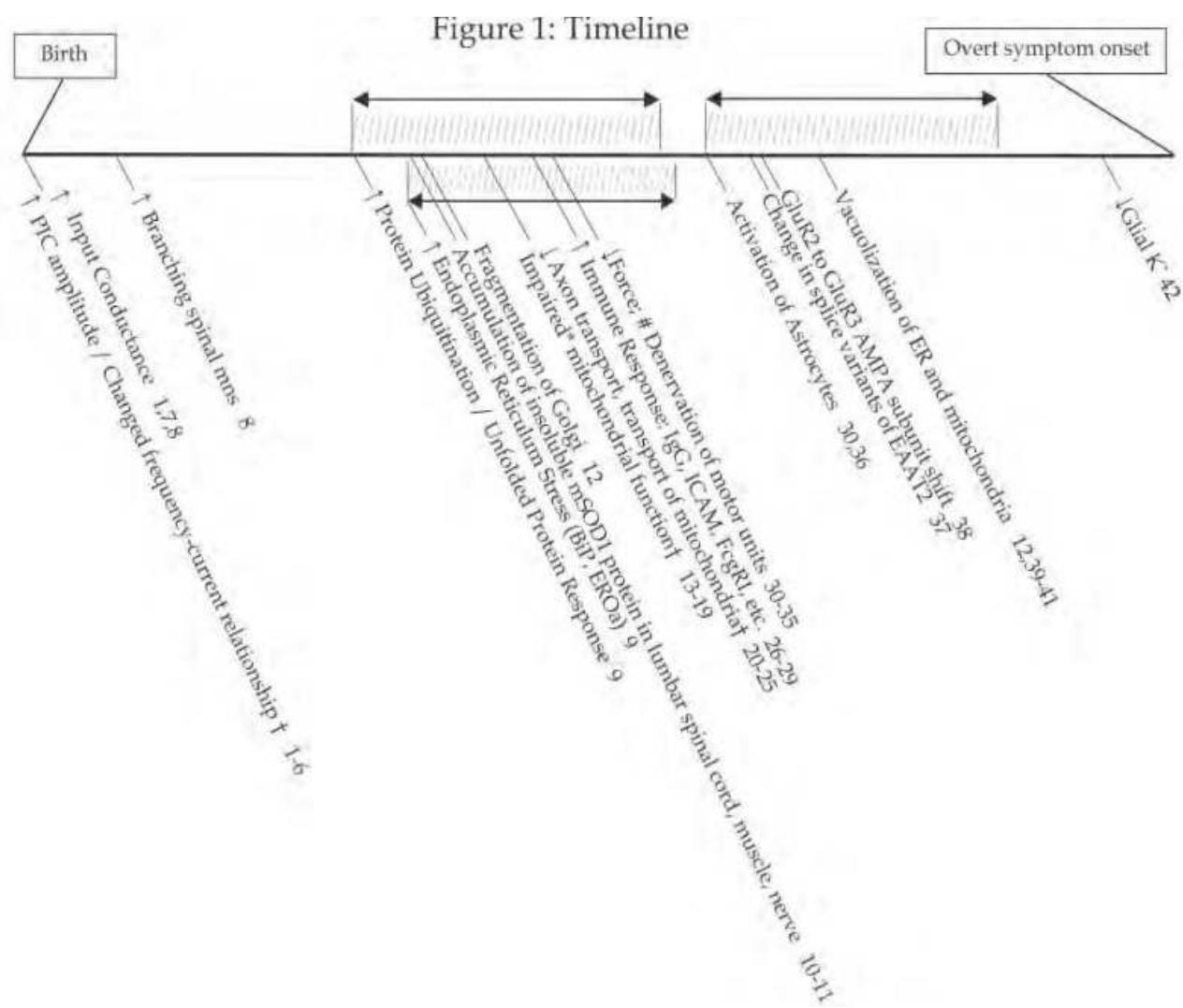

${ }^{1}$ (Quinlan et al., 2011), 2(Kuo et al., 2005), ${ }^{3}$ (van Zundert et al., 2008), ${ }^{4}$ (Meehan et al., 2010), 5 (Carunchio et al., 2010), ${ }^{6}$ (Pieri et al., 2009), ${ }^{7}$ (Bories et al., 2007), ${ }^{8}$ (Amendola and Durand, 2008), ${ }^{9}$ (Saxena et al., 2009), ${ }^{10}$ (Johnston et al., 2000), ${ }^{11}$ (Turner et al., 2003b), 12(Mourelatos et al., 1996), ${ }^{13}$ (Li et al., 2010), ${ }^{14}$ (Jaiswal and Keller, 2009),15(Mattiazzi et al., 2002), ${ }^{16}$ (Nguyen et al., 2009), ${ }^{17}$ (Jaiswal et al., 2009), ${ }^{18}$ (Bilsland et al., 2008), ${ }^{19}$ (Damiano et al., 2006), ${ }^{20}$ (Bilsland et al., 2010), ${ }^{21}$ (De Vos et al., 2007), ${ }^{22}$ (Williamson and Cleveland, 1999), ${ }^{23}$ (Zhang et al., 1997), ${ }^{24}$ (Kieran et al., 2005), ${ }^{25}$ (Warita et al., 1999), ${ }^{26}$ (Alexianu et al., 2001), ${ }^{27}$ (Gowing et al., 2008), ${ }^{28}$ (Chiu et al., 2008), ${ }^{29}$ (Chiu et al., 2009), ${ }^{30}$ (Fischer et al., 2004), ${ }^{31}$ (Frey et al., 2000), ${ }^{32}$ (Pun et al., 2006), ${ }^{33}$ (Hegedus et al., 2007), ${ }^{34}$ (Hegedus et al., 2008), ${ }^{35}$ (Kennel et al., 1996), 36(Bruijn et al., 1997), 37(Munch et al., 2002), ${ }^{38}$ (Tortarolo et al., 2006), 39(Bendotti et al., 2001), ${ }^{40}$ (Dal Canto and Gurney, 1995), ${ }^{41}$ (Dal Canto and Gurney, 1994), ${ }^{42}$ (Kaiser et al., 2006).

Fig. 1. Timeline of deficits in mutant SOD1 mice. Earliest reported deficits in the above properties are used. Different SOD1 mutants were normalized to dates of overt symptom onset. When differences in timing between mouse lines were large (as it was for protein ubiquitination, stress of the ER, and activation of astrocytes), the range is indicated in the timeline with $(/ / /)$. $†$ Also found in embryonic cultured motoneurons. * Different aspects of mitochondrial function were impaired at different time points. The first alteration in function is decreased $\mathrm{Ca}^{2+}$ storage capacity ${ }^{19}$. Another property, mitochondrial membrane potential, is not altered until just before symptom onset ${ }^{17}$, while the function or regulation of the electron transport chain is impaired slightly before membrane potential ${ }^{16}$. 
While $\mathrm{Ca}^{2+}$ currents are increased in SOD1 motoneurons, large spinal and hypoglossal motoneurons do not have $\mathrm{Ca}^{2+}$-binding proteins calbindin and parvalbumin and thus cannot quickly neutralize large influxes of $\mathrm{Ca}^{2+}$. Instead, they depend heavily on mitochondrial uptake of $\mathrm{Ca}^{2+}$ (Ren and Ruda, 1994, Lips and Keller, 1998, Palecek et al., 1999, Bergmann and Keller, 2004). Small ocular motoneurons which have calbindin, parvalbumin and high $\mathrm{Ca}^{2+}$-buffering capacities are unaffected by ALS (Vanselow and Keller, 2000, von Lewinski and Keller, 2005). Ca ${ }^{2+}$-binding ratio, Ks, depends on $\mathrm{Ca}^{2+}$ binding proteins, the intracellular $\left[\mathrm{Ca}^{2+}\right]_{i}$, and the size and geometry of the cell (Neher, 1995). Although $\mathrm{Ca}^{2+}$ buffering at the soma of neonatal SOD1 and WT motoneurons was similar (von Lewinski et al., 2008), buffering has not been measured in adult motoneurons or in the processes, where $\mathrm{Ca}^{2+}$ channels are located (Sukiasyan et al., 2009). $\mathrm{Ca}^{2+}$ buffering could also change postnatally in motoneurons, as in rat Purkinje cells in which the $\mathrm{Ca}^{2+-b i n d i n g}$ ratio more than doubles between P6 and P15 (Fierro and Llano, 1996). The increasing $\mathrm{Ca}^{2+}$ entry with postnatal maturation combined with the lack of $\mathrm{Ca}^{2+}$-buffering proteins seems likely to contribute to motoneuronal vulnerability in adulthood.

\section{Impaired transport, more places to go}

The lack of $\mathrm{Ca}^{2+}$-buffering proteins in vulnerable motoneurons make the mitochondria even more critical to their function. Mitochondria are normally highly mobile both in axons and dendrites (MacAskill et al., 2010). Mitochondrial movement can be halted by increased concentrations of ADP, so they tend to remain in compartments which are highly metabolically-active (Mironov, 2007). Mitochondrial movements are also regulated through $\mathrm{Ca}^{2+}$ signaling and synaptic activity (Rintoul et al., 2003, Yi et al., 2004, Macaskill et al., 2009). When glutamate binds NMDA- or certain AMPA-type receptor-channels, it allows the influx of $\mathrm{Na}^{+}$and $\mathrm{Ca}^{2+}$ into the cell. The $\mathrm{Ca}^{2+}$-sensitive domain of Miro, the mitochondrial trafficking protein, then interacts with $\mathrm{Ca}^{2+}$ and the transport factors TRAK and KIF5, and pauses in its movement at active synapses (Rintoul et al., 2003, MacAskill et al., 2009). Postsynaptic NMDA receptors are also associated with PSD95 and with nitric oxide synthase (NOS) which, through nitric oxide (NO), also pauses mitochondrial movement (Rintoul et al., 2006). Once at a synapse, the mitochondria are probably tethered by neurofilaments, a process that depends both on the state of phosphorylation of the neurofilaments and a high mitochondrial membrane potential which indicates a high level of activity (Wagner et al., 2003).

In axons, but not in the soma of cultured SOD1 motoneurons, mitochondria are more sparsely distributed (De Vos et al., 2007), and in vivo mitochondria show more frequent pauses in their movements in pre-symptomatic SOD1 mice (Bilsland et al., 2010). Unfortunately, movement of mitochondria and other membrane-bound organelles has not yet been well studied in the dendrites of SOD1 motoneurons. If the mitochondria are similarly sparse in the dendrites, where most $\mathrm{Ca}^{2+}$ channels are located, this could have serious consequences for $\mathrm{Ca}^{2+}$ buffering. Spinal motoneurons of SOD1 mice show a significant proliferation in dendritic branches (Amendola and Durand, 2008) and an increased $\mathrm{Ca}^{2+}$ PIC (Quinlan et al., 2011), which could make mitochondrial motility in the dendrites more challenging. Without mitochondria to take up $\mathrm{Ca}^{2+}$ at the synapses, this would further exacerbate the low $\mathrm{Ca}^{2+}$ buffering in vulnerable motoneurons and any increased $\mathrm{Ca}^{2+}$ entry with synaptic inputs (Tortarolo et al., 2006). It is also worth noting that 
the motoneurons that are vulnerable are the largest: the fast, fatiguable alpha motoneurons (Pun et al., 2006, Hegedus et al., 2007, Hegedus et al., 2008). Evidence for further increases size in SOD1 motoneurons is reviewed in the previous chapter by Elbasiouny et al. Perhaps the size of the motoneuron and deficits in transport go hand in hand to produce vulnerability.

Axon transport has been extensively studied and is likely to contribute to ALS and to several neurodegenerative diseases, reviewed by (De Vos et al., 2008). In ALS, both slow and fast axon transport appear to be altered (Zhang et al., 1997, Warita et al., 1999, Williamson and Cleveland, 1999, Kieran et al., 2005, De Vos et al., 2007, Bilsland et al., 2010). Excessive glutamate could cause these deficiencies: high levels of glutamate activate a family of mitogen-activated protein kinases that phosphorylate neurofilaments, thereby decreasing transport (Ackerley et al., 2000, Hiruma et al., 2003, Stevenson et al., 2009). This process can be induced by NMDA or AMPA, blocked by removal of extracellular $\mathrm{Ca}^{2+}$, or reduced by application of riluzole (Hiruma et al., 2003, Stevenson et al., 2009). The protein kinases JNKs, cdk/p35 and p38, which phosphorylate heavy and light chains of kinesin and medium and heavy neurofilament sidearms, may link glutamate neurotransmission and axon transport deficits (Kawasaki et al., 1997, Schwarzschild et al., 1997, Ackerley et al., 2000, Brownlees et al., 2000, Lee et al., 2000). Further suggesting this, p38 has been found to be activated in SOD1 mice and ALS patients (Raoul et al., 2002, Tortarolo et al., 2003, Ackerley et al., 2004). Axon transport deficiencies occur early, with reports of impaired axonal integrity and dieback from the neuromuscular junction occurring weeks in advance of onset of symptoms in SOD1 mice, and appearing in cultured embryonic neurons (Kennel et al., 1996, Zhang et al., 1997, Williamson and Cleveland, 1999, Frey et al., 2000, Fischer et al., 2004, Pun et al., 2006, De Vos et al., 2007, Hegedus et al., 2007, Hegedus et al., 2008, Bilsland et al., 2010). Strengthening these results, transgenic TDP-43 mice show significantly lower levels of expression of heavy and light neurofilaments, though axon transport itself has not yet been assessed (Swarup et al., 2011).

\section{Mitochondrial deficiency and energy balance}

In motoneurons under normal conditions, the mitochondrial membrane potential powers both the $\mathrm{Ca}^{2+}$ uniporter and ATP synthase, so in periods of heavy $\mathrm{Ca}^{2+}$ influx, ATP production could be impaired (Mattson et al., 2008, Nguyen et al., 2009). The increased $\mathrm{Ca}^{2+}$ influx in SOD1 motoneurons is likely to further impair the function of mitochondria under these conditions. In addition, SOD1 mitochondria appear to be impaired in function under basal conditions (Mattiazzi et al., 2002, Nguyen et al., 2009, Li et al., 2010). Before the onset of symptoms, SOD1 mitochondria show decreased protein import, altered $\mathrm{Ca}^{2+}$ sequestering, and an exaggerated response of the electrical gradient of the inner membrane to stimulation-induced $\mathrm{Ca}^{2+}$ influx (Damiano et al., 2006, Bilsland et al., 2008, Jaiswal et al., 2009, Nguyen et al., 2009, Li et al., 2010). By the time symptoms appear there is severe damage to mitochondrial membrane potentials, respiration, the electron transport chain and ATP synthesis (Mattiazzi et al., 2002, Jaiswal and Keller, 2009). Another impairment is misfolded SOD1 binding to VDAC1, the general diffusion pore for anions and cations, including $\mathrm{Ca}^{2+}$. Both mitochondrial conductance and the uptake of ADP are thereby reduced, however, this is not observed until after the onset of symptoms (Israelson et al., 2010). Early alterations in SOD1 mitochondria must take place though another mechanism. 
In summary, not only are there fewer mitochondria present in the processes of SOD1 neurons (De Vos et al., 2007, Bilsland et al., 2010), but those that are present are impaired in functioning. This is likely to have dire consequences for both $\mathrm{Ca}^{2+}$ buffering and ATP production in the large and metabolically-active SOD1 motoneurons.

\section{Protein degradation and endoplasmic reticulum stress}

Misfolded proteins are degraded through autophagy (Yang and Klionsky, 2010). When the capacity of the cellular machinery in the ER to properly fold proteins is exceeded, cells react with the unfolded protein response (UPR) and signs of ER stress (reviewed by Ron and Walter, 2007). The UPR decreases most protein synthesis in the cell while upregulating synthesis of some ER proteins that assist in proper folding and processing of proteins. Another pathway, known as ER-associated protein degradation (ERAD), helps to clear the ER of misfolded proteins by exporting them to proteasomes where they are broken down (Bernasconi and Molinari, 2011). Proteins to be exported and degraded are marked by ubiquitination, a process in which ubiquitin molecules bind to the protein, tagging it for destruction (Bingol and Sheng, 2011). Normal ER function can be disrupted by blocking the ER-resident proteins from folding properly, inadequate functioning of the ubiquitinproteosome system, or failure to maintain a high level of $\mathrm{Ca}^{2+}$ inside the lumen of the ER (Paschen, 2003).

It is known that mice with the highest expression levels of mutant SOD1 protein have the earliest disease onset (Wong et al., 1995), and that markers for ER stress have been found in the spinal cords of sALS patients (Ilieva et al., 2007, Atkin et al., 2008, Ito et al., 2009). However, recent studies have shed more light on the role of protein degradation and ER stress in the pathology of ALS. In the first study, gene expression patterns from 3 different SOD1 mouse lines all showed an early increase in protein ubiquitination only in those motoneurons that are vulnerable to the disease. This is followed shortly by the UPR and signs of ER stress by P30 in SOD1G93A-high expressor mice (see Fig 1) (Saxena et al., 2009). In another study, cortical motoneurons from SOD1 mutant mice were compared to those from wild type mice that were fed a diet high in branched-chain amino acids (Carunchio et al., 2010). These branched chain amino acids are part of protein supplements that some athletes consume. Like mutant SOD1 neurons, cortical neurons from mice fed the highprotein diet were hyperexcitable compared with neurons from wild type mice on a normal diet. A return to normal levels of excitability after treatment with rapamycin was achieved for both the SOD1 and the amino- acid-supplement-treated cortical neurons (Carunchio et al., 2010). The protein kinase known as the mammalian target of rapamycin (mTOR) serves as an integration point for several cell signaling pathways. As its name suggests, mTOR is inhibited by rapamycin; it also inhibits protein degradation, and promotes increased cell size in some neurons (Lee et al., 2007). These results indicate that promoting autophagy with rapamycin can reduce abnormal excitability and could be beneficial for treatment of the disease (Carunchio et al., 2010). The third, most recent study described a mutation found in 5 different families, located in the gene encoding ubiquilin-2 as a novel genetic cause of fALS (Deng et al., 2011). The function of ubiquilin is to clear certain misfolded proteins during ERAD by shuttling ubiquitinated proteins from the ER to the proteasome, such that loss of ubiquilin leads to ER stress (Kim et al., 2008, Lim et al., 2009). The mutations in ubiquilin-2 found in ALS patients were also found to impair proteosome- mediated protein degradation in vitro, suggesting these mutations could be causing similar impairments in the 
families from whom they were isolated (Deng et al., 2011). Even in sALS patients, ubiquilin2 was found in abnormal protein aggregates in degenerating neurons, indicating it could play a broad role in both fALS and sALS pathology (Deng et al., 2011). These studies suggest a key role for protein degradation and ER stress in ALS pathology.

In healthy neurons, the resting $\left[\mathrm{Ca}^{2+}\right]$ in the ER remains high. When $E R\left[\mathrm{Ca}^{2+}\right]$ drops, the $\mathrm{Ca}^{2+}$-sensing STIM proteins promote $\mathrm{Ca}^{2+}$-channel formation (Luik et al., 2008). Blocking this ER-mediated $\mathrm{Ca}^{2+}$-entry affects neuronal activity and under conditions of chronic hyperexcitability, STIM proteins are upregulated (Steinbeck et al., 2011). Contributions to electrophysiological excitation-mediated $\mathrm{Ca}^{2+}$ transients from $\mathrm{ER} \mathrm{Ca}^{2+}$ release have been documented in motoneurons (Scamps et al., 2004, Jahn et al., 2006). Supporting the possibility that neuronal excitability and neuronal protein processing and ER function could share common pathways, blocking L-type $\mathrm{Ca}^{2+}$ channels has been reported to increase autophagy (Williams et al., 2008). To summarize, due to the large role $\mathrm{Ca}^{2+}$ plays in cell signaling, (McCue et al., 2010, Pivovarova and Andrews, 2010), even small changes in electrophysiological properties could have broad consequences in cellular function.

\section{Non-cell autonomous deficits: Astrocytes and glutamate excitotoxicity}

Recent work has shown that the vulnerability of motoneurons is not cell autonomous, and that glia play critical roles in neurodegeneration in SOD1 mice. The involvement of astrocytes and microglia in the disease were elegantly demonstrated in a series of studies using mice with deletable mutant SOD1, mice with a selective knockdown of SOD1, and SOD1/WT chimera mice (Clement et al., 2003, Boillee et al., 2006, Yamanaka et al., 2008, Wang et al., 2009). Simply culturing WT motoneurons on mutant SOD1 astrocytes was sufficient to confer toxicity to motoneurons (Nagai et al., 2007). Glia have this effect on motoneurons through a variety of pathways, including activation of astrocytes, microglia, and $\mathrm{T}$ cells shortly after the first signs of pathology appear. The glial response is thought to influence the progression, but not the onset, of the disease (Beers et al., 2006, Boillee et al., 2006, Yamanaka et al., 2008, Wang et al., 2009, Philips and Robberecht, 2011). Presymptomatic involvement of the glia includes a reduction of glial $\mathrm{K}^{+}$channel expression shortly before the onset of symptoms (Kaiser et al., 2006) and later in the course of the disease, a reduced expression of astroglial glutamate transporters, GLT1/EAAT2 which mediate glutamate reuptake at synapses and help prevent glutamate excitotoxicity (Bruijn et al., 1997, Bendotti et al., 2001, Warita et al., 2002). Earlier alterations in EAAT2 function are likely due to expression of different splice variants rather than decreased expressions levels (Sasaki et al., 2001, Munch et al., 2002, Ignacio et al., 2005). Some ALS patients also show abnormal splice variants of EAAT2, which could lead to decreased glutamate transport (Rothstein et al., 1992, Maragakis et al., 2004, Lauriat et al., 2007). Stimulation of the expression and transporter activity of EAAT2/GLT1 increases the lifespan of mutant SOD1 mice (Rothstein et al., 2005). An additional, critical function of the glia is regulation of the glutamate receptor's pore-forming GluR2 subunit (Van Damme et al., 2007). The challenges of $\mathrm{Ca}^{2+}$ buffering are exacerbated by alterations in the glutamate signaling across disease models of ALS. In SOD1 motoneurons, expression of subunits in the AMPA-type glutamate receptors is shifted from $\mathrm{Ca}^{2+}$-impermeable to $\mathrm{Ca}^{2+}$-permeable (Tortarolo et al., 2006). In TDP mice, levels of RNA that encode proteins involved in synaptic activity, including glutamate receptors, ion channels and voltage gated $\mathrm{Ca} 2+$ channels, are altered, with unknown consequences on synaptic transmission (Polymenidou et al., 2011). Lastly, in sALS 
patients, there is inefficient editing of AMPRA receptor GluR2Q subunit mRNA which also causes a shift from $\mathrm{Ca}^{2+}$-impermeability of the receptors to $\mathrm{Ca}^{2+}$-permeability (Kawahara et al., 2004, Kwak and Kawahara, 2005, Kawahara et al., 2006). Glutamatergic signaling is probably a significant factor in the onset of symptoms since reducing excitatory sensory input delayed the onset of disease in SOD1 mice (Ilieva et al., 2008), and intrathecal administration of the glutamate agonist kainic acid in normal rats produced slow, selective motoneuron death similar to ALS (Sun et al., 2006). If changes in the transmission of glutamate are taking place early enough, it could alter the activity of spinal networks during normal development (Blankenship and Feller, 2010, Landmesser and O'Donovan, 1984, Marder and Rehm, 2005, Gonzalez-Islas and Wenner, 2006). Some evidence for alterations in network activity has been shown in SOD1 hypoglossal motoneurons (van Zundert et al., 2008) and spinal motoneurons (Amendola et al., 2004, Bories et al., 2007) in juvenile mice. After symptom onset, increased network activity has also been shown in the spinal cord (Jiang et al., 2009). However, considering all the documented changes in glutamatemediated neurotransmission, there has been surprisingly little research into the overall effects on cortical, brainstem and spinal network activity throughout the lifespan of the SOD1 mouse.

\section{Future directions}

There are many possibilities to explore for new treatments of ALS besides the nowstandard drug riluzole (Bellingham, 2011). The neuroinflammation response is a promising approach (Philips and Robberecht, 2011); another could be to manipulate neuromodulatory input to the spinal cord. Serotonin (5HT) and norepinephrine (NE) have potent effects on motoneurons, including increasing PIC amplitude, decreasing input conductance, hyperpolarizing spike threshold, and depolarizing resting potential (Hounsgaard and Kiehn, 1989, Lee and Heckman, 1999, Powers and Binder, 2001, Alaburda et al., 2002, Hultborn et al., 2004, Perrier and Delgado-Lezama, 2005, Heckman et al., 2008). Furthermore, neuromodulators are constantly scaling the level of activation of motoneurons as needed (Heckman et al., 2004). Activation of $5 \mathrm{HT}_{2}$ receptors strongly depresses high-voltage-activated $\mathrm{Ca}^{2+}$ channels while probably increasing basal $\left[\mathrm{Ca}^{2+}\right]_{\mathrm{I}}$ by potentiating the $\mathrm{Ca}^{2+}$ PIC (Hounsgaard et al., 1988, Bayliss et al., 1995, Hsiao et al., 1998, Ladewig et al., 2004, Li et al., 2007). Both 5HT and dopamine (DA) modulate KIF-5dependent cellular transport, including transport of mitochondria. Acting through the GSK3 regulator of KIF-5, 5HT is observed to increase transport, while DA decreases it (Chen et al., 2007, Chen et al., 2008). Other neuromodulators, such as nitric oxide, GABA $_{B}$, and adenosine, could also be worth investigating as modulators of motoneuron synaptic strength, reduction of the $\mathrm{Ca}^{2+}$ PIC, and modulation of both high-voltage-activated $\mathrm{Ca}^{2+}$ channels and input conductance, respectively (Marks et al., 1993, Mynlieff and Beam, 1994, Li et al., 2004, Moreno-Lopez et al., 2011). Another useful target of neuromodulators that modify $\mathrm{Ca}^{2+}$ influx is protein clearance; inhibition of L-type $\mathrm{Ca}^{2+}$ channels has been found to increase autophagy (Williams et al., 2008).

\section{Conclusions}

Factors causing neurodegeneration in ALS are present long before motor function is adversely affected. From research on the animal models of ALS, it is thought that excessive 
$\mathrm{Ca}^{2+}$ entry, increased motoneuronal size, altered glutamate neurotransmission, astrocyte dysfunction, mitochondrial deficits, failures in axon transport, and problems in protein degradation act in concert and gradually push motoneurons outside the parameters under which they can function properly. The fact that motoneurons are able to remain functioning for as long as they do under adverse conditions suggests that there is a large window of time and intrinsic conditions within which motoneurons can maintain normal function. Hopefully future treatments can target these altered pathways to extend the time motoneuron properties remain within these parameters.

\section{References}

Ackerley S, Grierson AJ, Banner S, Perkinton MS, Brownlees J, Byers HL, Ward M, Thornhill P, Hussain K, Waby JS, Anderton BH, Cooper JD, Dingwall C, Leigh PN, Shaw CE, Miller CC (2004) p38alpha stress-activated protein kinase phosphorylates neurofilaments and is associated with neurofilament pathology in amyotrophic lateral sclerosis. Mol Cell Neurosci 26:354-364.

Ackerley S, Grierson AJ, Brownlees J, Thornhill P, Anderton BH, Leigh PN, Shaw CE, Miller CC (2000) Glutamate slows axonal transport of neurofilaments in transfected neurons. J Cell Biol 150:165-176.

Alaburda A, Perrier JF, Hounsgaard J (2002) Mechanisms causing plateau potentials in spinal motoneurones. Adv Exp Med Biol 508:219-226.

Alexianu ME, Kozovska M, Appel SH (2001) Immune reactivity in a mouse model of familial ALS correlates with disease progression. Neurology 57:1282-1289.

Amendola J, Durand J (2008) Morphological differences between wild-type and transgenic superoxide dismutase 1 lumbar motoneurons in postnatal mice. J Comp Neurol 511:329-341.

Amendola J, Verrier B, Roubertoux P, Durand J (2004) Altered sensorimotor development in a transgenic mouse model of amyotrophic lateral sclerosis. Eur J Neurosci 20:28222826.

Atkin JD, Farg MA, Walker AK, McLean C, Tomas D, Horne MK (2008) Endoplasmic reticulum stress and induction of the unfolded protein response in human sporadic amyotrophic lateral sclerosis. Neurobiol Dis 30:400-407.

Bayliss DA, Umemiya M, Berger AJ (1995) Inhibition of N- and P-type calcium currents and the after-hyperpolarization in rat motoneurones by serotonin. Journal of Physiology 485:635-647.

Beers DR, Henkel JS, Xiao Q, Zhao W, Wang J, Yen AA, Siklos L, McKercher SR, Appel SH (2006) Wild-type microglia extend survival in PU.1 knockout mice with familial amyotrophic lateral sclerosis. Proc Natl Acad Sci U S A 103:16021-16026.

Bellingham MC (2011) A review of the neural mechanisms of action and clinical efficiency of riluzole in treating amyotrophic lateral sclerosis: what have we learned in the last decade? CNS Neurosci Ther 17:4-31.

Bendotti C, Tortarolo M, Suchak SK, Calvaresi N, Carvelli L, Bastone A, Rizzi M, Rattray M, Mennini T (2001) Transgenic SOD1 G93A mice develop reduced GLT-1 in spinal cord without alterations in cerebrospinal fluid glutamate levels. J Neurochem 79:737-746.

Bergmann F, Keller BU (2004) Impact of mitochondrial inhibition on excitability and cytosolic Ca2+ levels in brainstem motoneurones from mouse. J Physiol 555:45-59. 
Bernasconi R, Molinari M (2011) ERAD and ERAD tuning: disposal of cargo and of ERAD regulators from the mammalian ER. Curr Opin Cell Biol 23:176-183.

Bilsland LG, Nirmalananthan N, Yip J, Greensmith L, Duchen MR (2008) Expression of mutant SOD1 in astrocytes induces functional deficits in motoneuron mitochondria. J Neurochem 107:1271-1283.

Bilsland LG, Sahai E, Kelly G, Golding M, Greensmith L, Schiavo G (2010) Deficits in axonal transport precede ALS symptoms in vivo. Proc Natl Acad Sci U S A 107:2052320528.

Bingol B, Sheng M (2011) Deconstruction for reconstruction: the role of proteolysis in neural plasticity and disease. Neuron 69:22-32.

Blankenship AG, Feller MB (2010) Mechanisms underlying spontaneous patterned activity in developing neural circuits. Nat Rev Neurosci 11:18-29.

Boillee S, Yamanaka K, Lobsiger CS, Copeland NG, Jenkins NA, Kassiotis G, Kollias G, Cleveland DW (2006) Onset and progression in inherited ALS determined by motor neurons and microglia. Science 312:1389-1392.

Bories C, Amendola J, Lamotte d'Incamps B, Durand J (2007) Early electrophysiological abnormalities in lumbar motoneurons in a transgenic mouse model of amyotrophic lateral sclerosis. Eur J Neurosci 25:451-459.

Brownlees J, Yates A, Bajaj NP, Davis D, Anderton BH, Leigh PN, Shaw CE, Miller CC (2000) Phosphorylation of neurofilament heavy chain side-arms by stress activated protein kinase-1b/Jun N-terminal kinase-3. J Cell Sci 113 ( Pt 3):401-407.

Bruijn LI, Becher MW, Lee MK, Anderson KL, Jenkins NA, Copeland NG, Sisodia SS, Rothstein JD, Borchelt DR, Price DL, Cleveland DW (1997) ALS-linked SOD1 mutant G85R mediates damage to astrocytes and promotes rapidly progressive disease with SOD1-containing inclusions. Neuron 18:327-338.

Byrne S, Walsh C, Lynch C, Bede P, Elamin M, Kenna K, McLaughlin R, Hardiman O (2011) Rate of familial amyotrophic lateral sclerosis: a systematic review and metaanalysis. J Neurol Neurosurg Psychiatry 82:623-627.

Carunchio I, Curcio L, Pieri M, Pica F, Caioli S, Viscomi MT, Molinari M, Canu N, Bernardi G, Zona C (2010) Increased levels of p70S6 phosphorylation in the G93A mouse model of Amyotrophic Lateral Sclerosis and in valine-exposed cortical neurons in culture. Exp Neurol 226:218-230.

Chen S, Owens GC, Crossin KL, Edelman DB (2007) Serotonin stimulates mitochondrial transport in hippocampal neurons. Mol Cell Neurosci 36:472-483.

Chen S, Owens GC, Edelman DB (2008) Dopamine inhibits mitochondrial motility in hippocampal neurons. PLoS One 3:e2804.

Chiu IM, Chen A, Zheng Y, Kosaras B, Tsiftsoglou SA, Vartanian TK, Brown RH, Jr., Carroll MC (2008) T lymphocytes potentiate endogenous neuroprotective inflammation in a mouse model of ALS. Proc Natl Acad Sci U S A 105:17913-17918.

Chiu IM, Phatnani H, Kuligowski M, Tapia JC, Carrasco MA, Zhang M, Maniatis T, Carroll MC (2009) Activation of innate and humoral immunity in the peripheral nervous system of ALS transgenic mice. Proc Natl Acad Sci U S A 106:20960-20965.

Clement AM, Nguyen MD, Roberts EA, Garcia ML, Boillee S, Rule M, McMahon AP, Doucette W, Siwek D, Ferrante RJ, Brown RH, Jr., Julien JP, Goldstein LS, Cleveland DW (2003) Wild-type nonneuronal cells extend survival of SOD1 mutant motor neurons in ALS mice. Science 302:113-117. 
Dal Canto MC, Gurney ME (1994) Development of central nervous system pathology in a murine transgenic model of human amyotrophic lateral sclerosis. The American journal of pathology 145:1271-1279.

Dal Canto MC, Gurney ME (1995) Neuropathological changes in two lines of mice carrying a transgene for mutant human $\mathrm{Cu}, \mathrm{Zn} \mathrm{SOD}$, and in mice overexpressing wild type human SOD: a model of familial amyotrophic lateral sclerosis (FALS). Brain Res 676:25-40.

Damiano M, Starkov AA, Petri S, Kipiani K, Kiaei M, Mattiazzi M, Flint Beal M, Manfredi G (2006) Neural mitochondrial Ca2+ capacity impairment precedes the onset of motor symptoms in G93A $\mathrm{Cu} / \mathrm{Zn}$-superoxide dismutase mutant mice. J Neurochem 96:1349-1361.

De Vos KJ, Chapman AL, Tennant ME, Manser C, Tudor EL, Lau KF, Brownlees J, Ackerley S, Shaw PJ, McLoughlin DM, Shaw CE, Leigh PN, Miller CC, Grierson AJ (2007) Familial amyotrophic lateral sclerosis-linked SOD1 mutants perturb fast axonal transport to reduce axonal mitochondria content. Hum Mol Genet 16:2720-2728.

De Vos KJ, Grierson AJ, Ackerley S, Miller CC (2008) Role of axonal transport in neurodegenerative diseases. Annu Rev Neurosci 31:151-173.

Deng HX, Chen W, Hong ST, Boycott KM, Gorrie GH, Siddique N, Yang Y, Fecto F, Shi Y, Zhai H, Jiang H, Hirano M, Rampersaud E, Jansen GH, Donkervoort S, Bigio EH, Brooks BR, Ajroud K, Sufit RL, Haines JL, Mugnaini E, Pericak-Vance MA, Siddique T (2011) Mutations in UBQLN2 cause dominant X-linked juvenile and adult-onset ALS and ALS/dementia. Nature.

Elbasiouny SM, Amendola J, Durand J, Heckman CJ (2010) Evidence from computer simulations for alterations in the membrane biophysical properties and dendritic processing of synaptic inputs in mutant superoxide dismutase-1 motoneurons. J Neurosci In Press.

Fierro L, Llano I (1996) High endogenous calcium buffering in Purkinje cells from rat cerebellar slices. J Physiol 496 ( Pt 3):617-625.

Fischer LR, Culver DG, Tennant P, Davis AA, Wang M, Castellano-Sanchez A, Khan J, Polak MA, Glass JD (2004) Amyotrophic lateral sclerosis is a distal axonopathy: evidence in mice and man. Exp Neurol 185:232-240.

Frey D, Schneider C, Xu L, Borg J, Spooren W, Caroni P (2000) Early and selective loss of neuromuscular synapse subtypes with low sprouting competence in motoneuron diseases. J Neurosci 20:2534-2542.

Gonzalez-Islas C, Wenner P (2006) Spontaneous network activity in the embryonic spinal cord regulates AMPAergic and GABAergic synaptic strength. Neuron 49:563-575.

Gowing G, Philips T, Van Wijmeersch B, Audet JN, Dewil M, Van Den Bosch L, Billiau AD, Robberecht W, Julien JP (2008) Ablation of proliferating microglia does not affect motor neuron degeneration in amyotrophic lateral sclerosis caused by mutant superoxide dismutase. J Neurosci 28:10234-10244.

Gurney ME, Pu H, Chiu AY, Dal Canto MC, Polchow CY, Alexander DD, Caliendo J, Hentati A, Kwon YW, Deng HX, et al. (1994) Motor neuron degeneration in mice that express a human $\mathrm{Cu}, \mathrm{Zn}$ superoxide dismutase mutation. Science 264:17721775 . 
Heckman CJ, Johnson M, Mottram C, Schuster J (2008b) Persistent inward currents in spinal motoneurons and their influence on human motoneuron firing patterns. Neuroscientist 14:264-275.

Heckman CJ, Kuo JJ, Johnson MD (2004) Synaptic integration in motoneurons with hyperexcitable dendrites. Canadian journal of physiology and pharmacology 82:549-555.

Hegedus J, Putman CT, Gordon T (2007) Time course of preferential motor unit loss in the SOD1 G93A mouse model of amyotrophic lateral sclerosis. Neurobiol Dis 28:154164.

Hegedus J, Putman CT, Tyreman N, Gordon T (2008) Preferential motor unit loss in the SOD1 G93A transgenic mouse model of amyotrophic lateral sclerosis. J Physiol 586:3337-3351.

Hiruma H, Katakura T, Takahashi S, Ichikawa T, Kawakami T (2003) Glutamate and amyloid beta-protein rapidly inhibit fast axonal transport in cultured rat hippocampal neurons by different mechanisms. J Neurosci 23:8967-8977.

Hounsgaard J, Hultborn H, Jespersen B, Kiehn O (1988) Bistability of alpha-motoneurones in the decerebrate cat and in the acute spinal cat after intravenous 5hydroxytryptophan. J Physiol 405:345-367.

Hounsgaard J, Kiehn O (1989) Serotonin-induced bistability of turtle motoneurones caused by a nifedipine-sensitive calcium plateau potential. J Physiol Lond 414:265-282.

Hsiao CF, Del Negro CA, Trueblood PR, Chandler SH (1998) Ionic basis for serotonininduced bistable membrane properties in guinea pig trigeminal motoneurons. J Neurophysiol 79:2847-2856.

Hultborn H, Brownstone RB, Toth TI, Gossard JP (2004) Key mechanisms for setting the input-output gain across the motoneuron pool. Prog Brain Res 143:77-95.

Ignacio S, Moore DH, Smith AP, Lee NM (2005) Effect of neuroprotective drugs on gene expression in G93A/SOD1 mice. Ann N Y Acad Sci 1053:121-136.

Ilieva EV, Ayala V, Jove M, Dalfo E, Cacabelos D, Povedano M, Bellmunt MJ, Ferrer I, Pamplona R, Portero-Otin M (2007) Oxidative and endoplasmic reticulum stress interplay in sporadic amyotrophic lateral sclerosis. Brain 130:3111-3123.

Ilieva HS, Yamanaka K, Malkmus S, Kakinohana O, Yaksh T, Marsala M, Cleveland DW (2008) Mutant dynein (Loa) triggers proprioceptive axon loss that extends survival only in the SOD1 ALS model with highest motor neuron death. Proc Natl Acad Sci U S A 105:12599-12604.

Israelson A, Arbel N, Da Cruz S, Ilieva H, Yamanaka K, Shoshan-Barmatz V, Cleveland DW (2010) Misfolded mutant SOD1 directly inhibits VDAC1 conductance in a mouse model of inherited ALS. Neuron 67:575-587.

Ito Y, Yamada M, Tanaka H, Aida K, Tsuruma K, Shimazawa M, Hozumi I, Inuzuka T, Takahashi H, Hara H (2009) Involvement of CHOP, an ER-stress apoptotic mediator, in both human sporadic ALS and ALS model mice. Neurobiol Dis 36:470476.

Jahn K, Grosskreutz J, Haastert K, Ziegler E, Schlesinger F, Grothe C, Dengler R, Bufler J (2006) Temporospatial coupling of networked synaptic activation of AMPA-type glutamate receptor channels and calcium transients in cultured motoneurons. Neuroscience 142:1019-1029. 
Jaiswal MK, Keller BU (2009) Cu/Zn superoxide dismutase typical for familial amyotrophic lateral sclerosis increases the vulnerability of mitochondria and perturbs $\mathrm{Ca} 2+$ homeostasis in SOD1G93A mice. Mol Pharmacol 75:478-489.

Jaiswal MK, Zech WD, Goos M, Leutbecher C, Ferri A, Zippelius A, Carri MT, Nau R, Keller BU (2009) Impairment of mitochondrial calcium handling in a mtSOD1 cell culture model of motoneuron disease. BMC Neurosci 10:64.

Jiang M, Schuster JE, Fu R, Siddique T, Heckman CJ (2009) Progressive changes in synaptic inputs to motoneurons in adult sacral spinal cord of a mouse model of amyotrophic lateral sclerosis. J Neurosci 29:15031-15038.

Jiang Z, Rempel J, Li J, Sawchuk MA, Carlin KP, Brownstone RM (1999) Development of Ltype calcium channels and a nifedipine-sensitive motor activity in the postnatal mouse spinal cord. Eur J Neurosci 11:3481-3487.

Johnston JA, Dalton MJ, Gurney ME, Kopito RR (2000) Formation of high molecular weight complexes of mutant $\mathrm{Cu}, \mathrm{Zn}$-superoxide dismutase in a mouse model for familial amyotrophic lateral sclerosis. Proc Natl Acad Sci U S A 97:12571-12576.

Kaiser M, Maletzki I, Hulsmann S, Holtmann B, Schulz-Schaeffer W, Kirchhoff F, Bahr M, Neusch C (2006) Progressive loss of a glial potassium channel (KCNJ10) in the spinal cord of the SOD1 (G93A) transgenic mouse model of amyotrophic lateral sclerosis. J Neurochem 99:900-912.

Kawahara Y, Ito K, Sun H, Aizawa H, Kanazawa I, Kwak S (2004) Glutamate receptors: RNA editing and death of motor neurons. Nature 427:801.

Kawahara Y, Sun H, Ito K, Hideyama T, Aoki M, Sobue G, Tsuji S, Kwak S (2006) Underediting of GluR2 mRNA, a neuronal death inducing molecular change in sporadic ALS, does not occur in motor neurons in ALS1 or SBMA. Neurosci Res 54:11-14.

Kawasaki H, Morooka T, Shimohama S, Kimura J, Hirano T, Gotoh Y, Nishida E (1997) Activation and involvement of p38 mitogen-activated protein kinase in glutamateinduced apoptosis in rat cerebellar granule cells. J Biol Chem 272:18518-18521.

Kennel PF, Finiels F, Revah F, Mallet J (1996) Neuromuscular function impairment is not caused by motor neurone loss in FALS mice: an electromyographic study. Neuroreport 7:1427-1431.

Kieran D, Hafezparast M, Bohnert S, Dick JR, Martin J, Schiavo G, Fisher EM, Greensmith L (2005) A mutation in dynein rescues axonal transport defects and extends the life span of ALS mice. J Cell Biol 169:561-567.

Kim TY, Kim E, Yoon SK, Yoon JB (2008) Herp enhances ER-associated protein degradation by recruiting ubiquilins. Biochem Biophys Res Commun 369:741-746.

Kuo JJ, Siddique T, Fu R, Heckman CJ (2005) Increased persistent Na+ current and its effect on excitability in motoneurones cultured from mutant SOD1 mice. Journal of Physiology-London 563:843-854.

Kwak S, Kawahara Y (2005) Deficient RNA editing of GluR2 and neuronal death in amyotropic lateral sclerosis. J Mol Med (Berl) 83:110-120.

Ladewig T, Lalley PM, Keller BU (2004) Serotonergic modulation of intracellular calcium dynamics in neonatal hypoglossal motoneurons from mouse. Brain Res 1001:1-12.

Landmesser LT, O'Donovan MJ (1984) Activation patterns of embryonic chick hind limb muscles recorded in ovo and in an isolated spinal cord preparation. J Physiol 347:189-204. 
Lauriat TL, Richler E, McInnes LA (2007) A quantitative regional expression profile of EAAT2 known and novel splice variants reopens the question of aberrant EAAT2 splicing in disease. Neurochemistry international 50:271-280.

Lee $\mathrm{CH}$, Inoki K, Guan KL (2007) mTOR pathway as a target in tissue hypertrophy. Annual review of pharmacology and toxicology 47:443-467.

Lee MS, Kwon YT, Li M, Peng J, Friedlander RM, Tsai LH (2000) Neurotoxicity induces cleavage of p35 to p25 by calpain. Nature 405:360-364.

Lee RH, Heckman CJ (1999) Enhancement of bistability in spinal motoneurons in vivo by the noradrenergic alpha1 agonist methoxamine. Journal of neurophysiology 81:21642174.

Li Q, Vande Velde C, Israelson A, Xie J, Bailey AO, Dong MQ, Chun SJ, Roy T, Winer L, Yates JR, Capaldi RA, Cleveland DW, Miller TM (2010) ALS-linked mutant superoxide dismutase 1 (SOD1) alters mitochondrial protein composition and decreases protein import. Proc Natl Acad Sci U S A 107:21146-21151.

Li X, Murray K, Harvey PJ, Ballou EW, Bennett DJ (2007) Serotonin facilitates a persistent calcium current in motoneurons of rats with and without chronic spinal cord injury. J Neurophysiol 97:1236-1246.

Li Y, Li X, Harvey PJ, Bennett DJ (2004) Effects of baclofen on spinal reflexes and persistent inward currents in motoneurons of chronic spinal rats with spasticity. J Neurophysiol 92:2694-2703.

Lim PJ, Danner R, Liang J, Doong H, Harman C, Srinivasan D, Rothenberg C, Wang H, Ye Y, Fang S, Monteiro MJ (2009) Ubiquilin and p97/VCP bind erasin, forming a complex involved in ERAD. J Cell Biol 187:201-217.

Lips MB, Keller BU (1998) Endogenous calcium buffering in motoneurones of the nucleus hypoglossus from mouse. J Physiol 511 ( Pt 1):105-117.

Luik RM, Wang B, Prakriya M, Wu MM, Lewis RS (2008) Oligomerization of STIM1 couples ER calcium depletion to CRAC channel activation. Nature 454:538-542.

MacAskill AF, Atkin TA, Kittler JT (2010) Mitochondrial trafficking and the provision of energy and calcium buffering at excitatory synapses. Eur J Neurosci 32:231-240.

Macaskill AF, Rinholm JE, Twelvetrees AE, Arancibia-Carcamo IL, Muir J, Fransson A, Aspenstrom P, Attwell D, Kittler JT (2009) Miro1 is a calcium sensor for glutamate receptor-dependent localization of mitochondria at synapses. Neuron 61:541-555.

Mackenzie IR, Rademakers R, Neumann M (2010) TDP-43 and FUS in amyotrophic lateral sclerosis and frontotemporal dementia. Lancet Neurol 9:995-1007.

Maragakis NJ, Dykes-Hoberg M, Rothstein JD (2004) Altered expression of the glutamate transporter EAAT2b in neurological disease. Ann Neurol 55:469-477.

Marder E, Rehm KJ (2005) Development of central pattern generating circuits. Curr Opin Neurobiol 15:86-93.

Marks JD, Donnelly DF, Haddad GG (1993) Adenosine-induced inhibition of vagal motoneuron excitability: receptor subtype and mechanisms. Am J Physiol 264:L124132.

Mattiazzi M, D'Aurelio M, Gajewski CD, Martushova K, Kiaei M, Beal MF, Manfredi G (2002) Mutated human SOD1 causes dysfunction of oxidative phosphorylation in mitochondria of transgenic mice. J Biol Chem 277:29626-29633.

Mattson MP, Gleichmann M, Cheng A (2008) Mitochondria in neuroplasticity and neurological disorders. Neuron 60:748-766. 
McCue HV, Haynes LP, Burgoyne RD (2010) The diversity of calcium sensor proteins in the regulation of neuronal function. Cold Spring Harb Perspect Biol 2:a004085.

Meehan CF, Moldovan M, Marklund SL, Graffmo KS, Nielsen JB, Hultborn H (2010) Intrinsic properties of lumbar motor neurones in the adult G127insTGGG superoxide dismutase-1 mutant mouse in vivo: evidence for increased persistent inward currents. Acta Physiol (Oxf) 200:361-376.

Mironov SL (2007) ADP regulates movements of mitochondria in neurons. Biophys J 92:2944-2952.

Moreno-Lopez B, Sunico CR, Gonzalez-Forero D (2011) NO orchestrates the loss of synaptic boutons from adult "sick" motoneurons: modeling a molecular mechanism. Mol Neurobiol 43:41-66.

Mourelatos Z, Gonatas NK, Stieber A, Gurney ME, Dal Canto MC (1996) The Golgi apparatus of spinal cord motor neurons in transgenic mice expressing mutant $\mathrm{Cu}, \mathrm{Zn}$ superoxide dismutase becomes fragmented in early, preclinical stages of the disease. Proc Natl Acad Sci U S A 93:5472-5477.

Munch C, Ebstein M, Seefried U, Zhu B, Stamm S, Landwehrmeyer GB, Ludolph AC, Schwalenstocker B, Meyer T (2002) Alternative splicing of the 5'-sequences of the mouse EAAT2 glutamate transporter and expression in a transgenic model for amyotrophic lateral sclerosis. J Neurochem 82:594-603.

Mynlieff M, Beam KG (1994) Adenosine acting at an A1 receptor decreases N-type calcium current in mouse motoneurons. J Neurosci 14:3628-3634.

Nagai M, Re DB, Nagata T, Chalazonitis A, Jessell TM, Wichterle H, Przedborski S (2007) Astrocytes expressing ALS-linked mutated SOD1 release factors selectively toxic to motor neurons. Nat Neurosci 10:615-622.

Neher E (1995) The use of fura-2 for estimating Ca buffers and Ca fluxes. Neuropharmacology 34:1423-1442.

Nguyen KT, Garcia-Chacon LE, Barrett JN, Barrett EF, David G (2009) The Psi(m) depolarization that accompanies mitochondrial $\mathrm{Ca} 2+$ uptake is greater in mutant SOD1 than in wild-type mouse motor terminals. Proc Natl Acad Sci U S A 106:20072011.

Nishimura AL, Mitne-Neto M, Silva HC, Richieri-Costa A, Middleton S, Cascio D, Kok F, Oliveira JR, Gillingwater T, Webb J, Skehel P, Zatz M (2004) A mutation in the vesicle-trafficking protein VAPB causes late-onset spinal muscular atrophy and amyotrophic lateral sclerosis. American journal of human genetics 75:822-831.

Palecek J, Lips MB, Keller BU (1999) Calcium dynamics and buffering in motoneurones of the mouse spinal cord. J Physiol 520 Pt 2:485-502.

Pardo CA, Xu Z, Borchelt DR, Price DL, Sisodia SS, Cleveland DW (1995) Superoxide dismutase is an abundant component in cell bodies, dendrites, and axons of motor neurons and in a subset of other neurons. Proc Natl Acad Sci U S A 92:954-958.

Paschen W (2003) Endoplasmic reticulum: a primary target in various acute disorders and degenerative diseases of the brain. Cell calcium 34:365-383.

Perrier JF, Delgado-Lezama R (2005) Synaptic release of serotonin induced by stimulation of the raphe nucleus promotes plateau potentials in spinal motoneurons of the adult turtle. J Neurosci 25:7993-7999.

Philips T, Robberecht W (2011) Neuroinflammation in amyotrophic lateral sclerosis: role of glial activation in motor neuron disease. Lancet Neurol 10:253-263. 
Pieri M, Carunchio I, Curcio L, Mercuri NB, Zona C (2009) Increased persistent sodium current determines cortical hyperexcitability in a genetic model of amyotrophic lateral sclerosis. Exp Neurol 215:368-379.

Pivovarova NB, Andrews SB (2010) Calcium-dependent mitochondrial function and dysfunction in neurons. The FEBS journal 277:3622-3636.

Polymenidou M, Lagier-Tourenne C, Hutt KR, Huelga SC, Moran J, Liang TY, Ling SC, Sun E, Wancewicz E, Mazur C, Kordasiewicz H, Sedaghat Y, Donohue JP, Shiue L, Bennett CF, Yeo GW, Cleveland DW (2011) Long pre-mRNA depletion and RNA missplicing contribute to neuronal vulnerability from loss of TDP-43. Nat Neurosci 14:459-468.

Powers RK, Binder MD (2001) Input-output functions of mammalian motoneurons. Rev Physiol Biochem Pharmacol 143:137-263.

Pun S, Santos AF, Saxena S, Xu L, Caroni P (2006) Selective vulnerability and pruning of phasic motoneuron axons in motoneuron disease alleviated by CNTF. Nat Neurosci 9:408-419.

Quinlan KA, Schuster JE, Fu R, Siddique T, Heckman CJ (2011) Altered postnatal maturation of electrical properties in spinal motoneurons in a mouse model of amyotrophic lateral sclerosis. J Physiol 589:2245-2260.

Raoul C, Estevez AG, Nishimune H, Cleveland DW, deLapeyriere O, Henderson CE, Haase G, Pettmann B (2002) Motoneuron death triggered by a specific pathway downstream of Fas. potentiation by ALS-linked SOD1 mutations. Neuron 35:10671083.

Reaume AG, Elliott JL, Hoffman EK, Kowall NW, Ferrante RJ, Siwek DF, Wilcox HM, Flood DG, Beal MF, Brown RH, Jr., Scott RW, Snider WD (1996) Motor neurons in Cu/Zn superoxide dismutase-deficient mice develop normally but exhibit enhanced cell death after axonal injury. Nat Genet 13:43-47.

Ren K, Ruda MA (1994) A comparative study of the calcium-binding proteins calbindinD28K, calretinin, calmodulin and parvalbumin in the rat spinal cord. Brain Res Brain Res Rev 19:163-179.

Rintoul GL, Bennett VJ, Papaconstandinou NA, Reynolds IJ (2006) Nitric oxide inhibits mitochondrial movement in forebrain neurons associated with disruption of mitochondrial membrane potential. J Neurochem 97:800-806.

Rintoul GL, Filiano AJ, Brocard JB, Kress GJ, Reynolds IJ (2003) Glutamate decreases mitochondrial size and movement in primary forebrain neurons. J Neurosci 23:7881-7888.

Ron D, Walter P (2007) Signal integration in the endoplasmic reticulum unfolded protein response. Nat Rev Mol Cell Biol 8:519-529.

Rosen DR, Siddique T, Patterson D, Figlewicz DA, Sapp P, Hentati A, Donaldson D, Goto J, O'Regan JP, Deng HX, et al. (1993) Mutations in Cu/Zn superoxide dismutase gene are associated with familial amyotrophic lateral sclerosis. Nature 362:59-62.

Rothstein JD, Martin LJ, Kuncl RW (1992) Decreased glutamate transport by the brain and spinal cord in amyotrophic lateral sclerosis. N Engl J Med 326:1464-1468.

Rothstein JD, Patel S, Regan MR, Haenggeli C, Huang YH, Bergles DE, Jin L, Dykes Hoberg M, Vidensky S, Chung DS, Toan SV, Bruijn LI, Su ZZ, Gupta P, Fisher PB (2005) Beta-lactam antibiotics offer neuroprotection by increasing glutamate transporter expression. Nature 433:73-77. 
Sasaki S, Warita H, Abe K, Komori T, Iwata M (2001) EAAT1 and EAAT2 immunoreactivity in transgenic mice with a G93A mutant SOD1 gene. Neuroreport 12:1359-1362.

Saxena S, Cabuy E, Caroni P (2009) A role for motoneuron subtype-selective ER stress in disease manifestations of FALS mice. Nat Neurosci 12:627-636.

Scamps F, Roig A, Boukhaddaoui H, Andre S, Puech S, Valmier J (2004) Activation of P-type calcium channel regulates a unique thapsigargin-sensitive calcium pool in embryonic motoneurons. Eur J Neurosci 19:977-982.

Schwarzschild MA, Cole RL, Hyman SE (1997) Glutamate, but not dopamine, stimulates stress-activated protein kinase and AP-1-mediated transcription in striatal neurons. J Neurosci 17:3455-3466.

Steinbeck JA, Henke N, Opatz J, Gruszczynska-Biegala J, Schneider L, Theiss S, Hamacher N, Steinfarz B, Golz S, Brustle O, Kuznicki J, Methner A (2011) Store-operated calcium entry modulates neuronal network activity in a model of chronic epilepsy. Exp Neurol.

Stevenson A, Yates DM, Manser C, De Vos KJ, Vagnoni A, Leigh PN, McLoughlin DM, Miller CC (2009) Riluzole protects against glutamate-induced slowing of neurofilament axonal transport. Neurosci Lett 454:161-164.

Sukiasyan N, Hultborn H, Zhang M (2009) Distribution of calcium channel Ca(V)1.3 immunoreactivity in the rat spinal cord and brain stem. Neuroscience 159:217235.

Sun H, Kawahara Y, Ito K, Kanazawa I, Kwak S (2006) Slow and selective death of spinal motor neurons in vivo by intrathecal infusion of kainic acid: implications for AMPA receptor-mediated excitotoxicity in ALS. Journal of neurochemistry 98:782791.

Swarup V, Phaneuf D, Bareil C, Robertson J, Rouleau GA, Kriz J, Julien JP (2011) Pathological hallmarks of amyotrophic lateral sclerosis/frontotemporal lobar degeneration in transgenic mice produced with TDP-43 genomic fragments. Brain.

Tortarolo M, Grignaschi G, Calvaresi N, Zennaro E, Spaltro G, Colovic M, Fracasso C, Guiso G, Elger B, Schneider H, Seilheimer B, Caccia S, Bendotti C (2006) Glutamate AMPA receptors change in motor neurons of SOD1G93A transgenic mice and their inhibition by a noncompetitive antagonist ameliorates the progression of amytrophic lateral sclerosis-like disease. J Neurosci Res 83:134-146.

Tortarolo M, Veglianese P, Calvaresi N, Botturi A, Rossi C, Giorgini A, Migheli A, Bendotti C (2003) Persistent activation of p38 mitogen-activated protein kinase in a mouse model of familial amyotrophic lateral sclerosis correlates with disease progression. Mol Cell Neurosci 23:180-192.

Turner BJ, Lopes EC, Cheema SS (2003a) Neuromuscular accumulation of mutant superoxide dismutase 1 aggregates in a transgenic mouse model of familial amyotrophic lateral sclerosis. Neurosci Lett 350:132-136.

Turner BJ, Rembach A, Spark R, Lopes EC, Cheema SS (2003b) Opposing effects of low and high-dose clozapine on survival of transgenic amyotrophic lateral sclerosis mice. J Neurosci Res 74:605-613.

Van Damme P, Bogaert E, Dewil M, Hersmus N, Kiraly D, Scheveneels W, Bockx I, Braeken D, Verpoorten N, Verhoeven K, Timmerman V, Herijgers P, Callewaert G, Carmeliet P, Van Den Bosch L, Robberecht W (2007) Astrocytes regulate GluR2 
expression in motor neurons and their vulnerability to excitotoxicity. Proc Natl Acad Sci U S A 104:14825-14830.

Van Den Bosch L (2011) Genetic rodent models of amyotrophic lateral sclerosis. Journal of biomedicine \& biotechnology 2011:348765.

van Zundert B, Peuscher MH, Hynynen M, Chen A, Neve RL, Brown RH, Jr., ConstantinePaton M, Bellingham MC (2008) Neonatal neuronal circuitry shows hyperexcitable disturbance in a mouse model of the adult-onset neurodegenerative disease amyotrophic lateral sclerosis. J Neurosci 28:10864-10874.

Vanselow BK, Keller BU (2000) Calcium dynamics and buffering in oculomotor neurones from mouse that are particularly resistant during amyotrophic lateral sclerosis (ALS)-related motoneurone disease. J Physiol 525 Pt 2:433-445.

Vinay L, Brocard F, Pflieger JF, Simeoni-Alias J, Clarac F (2000) Perinatal development of lumbar motoneurons and their inputs in the rat. Brain research bulletin 53:635-647.

von Lewinski F, Fuchs J, Vanselow BK, Keller BU (2008) Low Ca2+ buffering in hypoglossal motoneurons of mutant SOD1 (G93A) mice. Neurosci Lett 445:224-228.

von Lewinski F, Keller BU (2005) Mitochondrial Ca2+ buffering in hypoglossal motoneurons from mouse. Neurosci Lett 380:203-208.

Wagner OI, Lifshitz J, Janmey PA, Linden M, McIntosh TK, Leterrier JF (2003) Mechanisms of mitochondria-neurofilament interactions. J Neurosci 23:9046-9058.

Wang L, Sharma K, Grisotti G, Roos RP (2009) The effect of mutant SOD1 dismutase activity on non-cell autonomous degeneration in familial amyotrophic lateral sclerosis. Neurobiol Dis 35:234-240.

Warita H, Itoyama Y, Abe K (1999) Selective impairment of fast anterograde axonal transport in the peripheral nerves of asymptomatic transgenic mice with a G93A mutant SOD1 gene. Brain Res 819:120-131.

Warita H, Manabe Y, Murakami T, Shiote M, Shiro Y, Hayashi T, Nagano I, Shoji M, Abe K (2002) Tardive decrease of astrocytic glutamate transporter protein in transgenic mice with ALS-linked mutant SOD1. Neurological research 24:577-581.

Williams A, Sarkar S, Cuddon P, Ttofi EK, Saiki S, Siddiqi FH, Jahreiss L, Fleming A, Pask D, Goldsmith P, O'Kane CJ, Floto RA, Rubinsztein DC (2008) Novel targets for Huntington's disease in an mTOR-independent autophagy pathway. Nature chemical biology 4:295-305.

Williamson TL, Cleveland DW (1999) Slowing of axonal transport is a very early event in the toxicity of ALS-linked SOD1 mutants to motor neurons. Nat Neurosci 2:50-56.

Wong PC, Pardo CA, Borchelt DR, Lee MK, Copeland NG, Jenkins NA, Sisodia SS, Cleveland DW, Price DL (1995) An adverse property of a familial ALS-linked SOD1 mutation causes motor neuron disease characterized by vacuolar degeneration of mitochondria. Neuron 14:1105-1116.

Xu W, Lipscombe D (2001) Neuronal Ca(V)1.3alpha(1) L-type channels activate at relatively hyperpolarized membrane potentials and are incompletely inhibited by dihydropyridines. J Neurosci 21:5944-5951.

Yamanaka K, Chun SJ, Boillee S, Fujimori-Tonou N, Yamashita H, Gutmann DH, Takahashi R, Misawa H, Cleveland DW (2008) Astrocytes as determinants of disease progression in inherited amyotrophic lateral sclerosis. Nat Neurosci 11:251-253.

Yang Z, Klionsky DJ (2010) Eaten alive: a history of macroautophagy. Nat Cell Biol 12:814822. 
Yi M, Weaver D, Hajnoczky G (2004) Control of mitochondrial motility and distribution by the calcium signal: a homeostatic circuit. J Cell Biol 167:661-672.

Zhang B, Tu P, Abtahian F, Trojanowski JQ, Lee VM (1997) Neurofilaments and orthograde transport are reduced in ventral root axons of transgenic mice that express human SOD1 with a G93A mutation. J Cell Biol 139:1307-1315. 
AMYOTROPHIC

LATERAL SCLEROSIS

Eaced by Marton H. maver

\section{Amyotrophic Lateral Sclerosis}

Edited by Prof. Martin Maurer
ISBN 978-953-307-806-9

Hard cover, 718 pages

Publisher InTech

Published online 20, January, 2012

Published in print edition January, 2012

Though considerable amount of research, both pre-clinical and clinical, has been conducted during recent years, Amyotrophic Lateral Sclerosis (ALS) remains one of the mysterious diseases of the 21st century. Great efforts have been made to develop pathophysiological models and to clarify the underlying pathology, and with novel instruments in genetics and transgenic techniques, the aim for finding a durable cure comes into scope. On the other hand, most pharmacological trials failed to show a benefit for ALS patients. In this book, the reader will find a compilation of state-of-the-art reviews about the etiology, epidemiology, and pathophysiology of ALS, the molecular basis of disease progression and clinical manifestations, the genetics familial ALS, as well as novel diagnostic criteria in the field of electrophysiology. An overview over all relevant pharmacological trials in ALS patients is also included, while the book concludes with a discussion on current advances and future trends in ALS research.

\section{How to reference}

In order to correctly reference this scholarly work, feel free to copy and paste the following:

Katharina A. Quinlan, Sherif M. Elbasiouny and C.J. Heckman (2012). Molecular and Electrical Abnormalities in the Mouse Model of Amyotrophic Lateral Sclerosis, Amyotrophic Lateral Sclerosis, Prof. Martin Maurer (Ed.), ISBN: 978-953-307-806-9, InTech, Available from: http://www.intechopen.com/books/amyotrophic-lateralsclerosis/molecular-and-electrical-abnormalities-in-the-mouse-model-of-amyotrophic-lateral-sclerosis

\section{INTECH}

open science | open minds

\section{InTech Europe}

University Campus STeP Ri

Slavka Krautzeka 83/A

51000 Rijeka, Croatia

Phone: +385 (51) 770447

Fax: +385 (51) 686166

www.intechopen.com

\section{InTech China}

Unit 405, Office Block, Hotel Equatorial Shanghai

No.65, Yan An Road (West), Shanghai, 200040, China 中国上海市延安西路65号上海国际贵都大饭店办公楼 405 单元

Phone: +86-21-62489820

Fax: $+86-21-62489821$ 
(C) 2012 The Author(s). Licensee IntechOpen. This is an open access article distributed under the terms of the Creative Commons Attribution 3.0 License, which permits unrestricted use, distribution, and reproduction in any medium, provided the original work is properly cited. 